\title{
Effects of corn processing, particle size, and diet form on performance of calves in bedded pens
}

\author{
H. G. Bateman II, T. M. Hill, ${ }^{1}$ J. M. Aldrich, and R. L. Schlotterbeck \\ Akey, Nutrition and Research Center, PO Box 5002, Lewisburg, OH 45338
}

\begin{abstract}
In a series of 5 trials, Holstein calves from zero to 12 wk old were housed in pens bedded with straw and fed diets to evaluate physical form of starters containing different processed corn on calf performance. Starters were formulated to have similar ingredient and nutrient compositions. Calves, initially less than 1 wk old, were housed in individual pens through 8 wk and weaned at $6 \mathrm{wk}$ in trial 1 and at $4 \mathrm{wk}$ in trials 2 and 3 . In trials 4 and 5 , calves initially 8 wk old were housed in group pens ( 6 calves/pen) from 8 to 12 wk. Trial 1 compared feeding calves a pelleted versus textured starter. Trial 2 compared feeding calves a textured starter versus feeding half meal starter with half textured starter. Trial 3 compared feeding calves textured starters containing whole, steam-flaked, or dry rolled corn. Trial 4 compared feeding calves textured starters containing steam-flaked versus dry rolled corn. Trial 5 compared feeding calves textured starters containing whole or dry rolled corn. Measurements included average daily gain (ADG), starter intake, feed efficiency, hip width change, body condition score change, fecal scores, and medical treatments. Physical form of starter feed did not affect any measurements in trials $1,3,4$, and 5 . In trial 2 , calves fed starters manufactured with large amounts of fines had $11 \%$ less feed intake and $6 \%$ slower ADG than calves fed a textured starter. When starters contained similar ingredient and nutrient contents, manufacturing processes did not affect calf performance unless the diet contained a significant amount of fines, which reduced intake and ADG.
\end{abstract}

Key words: corn, processing, starter, calf

\section{INTRODUCTION}

Porter et al. (2007) reported greater ADG, starter intake, and earlier initiation of rumination in neonatal calves fed a coarse meal diet versus a fine particle diet that had been pelleted. Franklin et al. (2003) reported

Received April 7, 2008.

Accepted September 18, 2008.

${ }^{1}$ Corresponding author: mhill@akey.com less starter intake and ADG in calves fed a pelleted versus textured starter, with the textured starter tending to support the most starter intake and ADG versus pelleted and meal starters. However, the ingredient and nutrient composition of their diets were not similar confounding the interpretation of results. Older papers with limited details of methods and diets (Lassiter et al., 1955; Gardner, 1967; Kertz et al., 1979) reported that starter intake and ADG was less when starters were fine meals versus pelleted fine meals or coarse particle grains as a mash or textured diet. Yet, finely ground corn is digested faster in the rumen and more completely over the total digestive tract than coarsely ground corn in dairy cattle (Remond et al., 2004) and in piglets (Healy et al., 1994). However, a minimal particle size is required because consumption of diets with too many fine particles can lead to rumen parakeratosis (Greenwood et al., 1997). Data reported by Porter et al. (2007) suggest that ruminal parakeratosis and bloat are minimized when $75 \%$ of the particles in a starter exceed $1,190 \mu \mathrm{m}$ in diameter.

Many commercial starters today are textured and contain coarsely rolled or ground grains, whole grains, protein, mineral and vitamin supplement pellets, and molasses. At times, soft pellets break up during handling or while exiting the pellet mill and contain large amounts of fines. Some manufacturers add molasses to starters to cover up fines or aid in customer appeal. However, large amounts of molasses can result in soft pellets that break up with subsequent handling of the feed. Further, large amounts of molasses have been shown to reduce feed intake and ADG of calves (Lesmeister and Heinrichs, 2005; Hill et al., 2008b) such that processing to reduce one concern with the manufacture of calf starters may result in increases to another concern. Meal or mash feeds contain large amounts of fines because they are intentionally unscreened. All of these types of starters that contain large amounts of fines may lead to poor acceptability, low intake, and reduced ADG in calves versus starters made with low fines.

Lesmeister and Heinrichs (2004) reported no differences in ADG when feeding starters manufactured with different coarsely processed corn to calves bedded with shavings. Other research with highly processed and 
gelatinized corn and sorghum in pelleted diets have not yielded consistent responses compared with conventional dry processing (Abdelgadir and Morrill, 1995; Abdelgadir et al., 1996a,b).

Although important information is present in the literature relative to the physical characteristics of a calf starter, the industry could benefit from a more systemic approach of research on this topic to confirm what specific form or forms of starters are best for calf performance. The objectives of these 5 trials were to evaluate form (coarse textured, completely pelleted, finely rolled meal with limited coarse particles) of starters containing corn and common coarse processing of corn (whole, dry rolled, steam flaked) for calves under 3 mo of age managed in pens bedded with straw. One hypothesis was that calves fed coarse, textured starters would have greater intake and ADG than calves fed pelleted starters or starters with a large amount of fine particles. Another hypothesis was intake and ADG of calves would not be affected by processing of the corn (whole, dry rolled, steam flaked).

\section{MATERIALS AND METHODS}

All calves used in this study were cared for using acceptable practices as described in the Guide for the Care and Use of Agricultural Animals in Agricultural Research and Teaching (FASS, 1999).

Trial 1 compared feeding calves a textured (TX) starter with coarsely rolled corn versus a completely pelleted $(\mathbf{P})$ starter with finely rolled corn (Table 1) from the same corn source. Complete starters were wet sieved (Shaver et al., 1988) using a vibratory sieve shaker (Fritsch, Oberstein, Germany) and geometric mean particle sizes were determined (ASAE, 1983). The textured starter had a geometric mean particle size of $2,103 \mu \mathrm{m}$ with $82 \%$ of the particles $>1,180 \mu \mathrm{m}$. The pelleted starter had a geometric mean particle size of $735 \mu \mathrm{m}$ with $2 \%$ of the particles $>1,180 \mu \mathrm{m}$. Both starters were formulated to have similar nutrient concentrations; however, ingredient composition differed slightly. Starters and fresh water were fed ad libitum. All calves were fed a $20 \%$ milk CP, $20 \%$ fat milk replacer (MR; Akey White Gold, Akey, Lewisburg, $\mathrm{OH}$ ) at $0.454 \mathrm{~kg} / \mathrm{d}$, halved into a.m. and p.m. feedings for 39 d, followed by $0.227 \mathrm{~kg} / \mathrm{d}$ on d 40 to 42 (a.m. feeding only). This trial used 48 Holstein bull calves (24/treatment $)<1$ wk of age from multiple dairy farms. Calves were received at approximately $1600 \mathrm{~h}$ after a 10 -h transit and immediately fed $0.227 \mathrm{~kg}$ of a nutrient and electrolyte product (Critical Care; Akey) reconstituted to $2 \mathrm{~L}$ with warm water. Their first MR was fed at the following a.m. feeding. Calves were then weighed, blood was sampled from the jugular vein, serum protein measured using an optical refractometer (Atago USA Inc., Bellevue, WA), and calves were randomly assigned to treatment. The trial lasted $56 \mathrm{~d}$ and was conducted during the months of June through September. The average ambient temperature inside the calf housing during the trial was $21^{\circ} \mathrm{C}$ and ranged from 5 to $31^{\circ} \mathrm{C}$ based on hourly measurements.

Trial 2 compared feeding calves TX with coarsely rolled corn and whole oats to feeding half finely rolled meal starter with half coarse textured starter (MT; Table 1). Starter MT was manufactured by mixing equal weights of starter TX with starter TX that had been purposely ground. Starter TX had a geometric mean particle size of $2,029 \mu \mathrm{m}$ with $81 \%$ of the particles $>1,180 \mu \mathrm{m}$. Starter MT had a geometric mean particle size of $813 \mu \mathrm{m}$ with $4 \%$ of the particles $>1,180 \mu \mathrm{m}$. Starters were formulated to have the same ingredient and nutrient concentrations. All calves were fed a $26 \%$ milk CP, $17 \%$ fat MR (Akey Pinnacle, Akey) at 0.681 $\mathrm{kg} / \mathrm{d}$, halved into a.m. and p.m. feedings for $25 \mathrm{~d}$, followed by $0.340 \mathrm{~kg} / \mathrm{d}$ on d 26 to 28 (a.m. feeding only). Holstein bull calves (48) that were 2 to $4 \mathrm{~d}$ old from a single dairy were received midday after a 3 -h transit. Calves were fed MR at the p.m. feeding. The day after arrival, calves were weighed, blood was sampled from the jugular vein, serum protein measured using an optical refractometer (Atago USA Inc.), and calves were randomly assigned to treatments. Trial 2 lasted $56 \mathrm{~d}$ and was conducted from November through January. The average ambient temperature in the calf housing facility was $4^{\circ} \mathrm{C}$ and ranged from -10 to $24^{\circ} \mathrm{C}$ based on hourly measurements.

Trial 3 compared feeding Holstein bull calves coarse textured starters containing whole ( $\mathbf{T W})$, steam-flaked (TS), or dry rolled (TR) corn (Table 2) from the same corn source. Starters had geometric mean particle sizes ranging from 2,153 to $2,942 \mu \mathrm{m}$ and 80 to $86 \%$ of the particles were $>1,180 \mu \mathrm{m}$. Starters were formulated to have identical ingredients and nutrient concentrations. All calves were fed $0.681 \mathrm{~kg} / \mathrm{d}$ of a $26 \%$ milk CP, $17 \%$ fat MR (Akey Pinnacle, Akey) halved into a.m. and p.m. feedings for $25 \mathrm{~d}$, followed by $0.340 \mathrm{~kg} / \mathrm{d}$ in d 26 to 28 (a.m. feeding only). Three- to 4-d-old Holstein bull calves (48; 16 calves per treatment) from a single dairy were received midday after a 3 -h transit. Calves were fed MR at the p.m. feeding. The day after arrival, calves were weighed, blood was sampled from the jugular vein, and serum protein measured using an optical refractometer (Atago USA Inc.). Calves were then randomly assigned to starter treatments. The trial lasted $56 \mathrm{~d}$ and was conducted from May through June. The average ambient temperature inside the calf housing during the trial was $18^{\circ} \mathrm{C}$ and ranged from 3 to $32^{\circ} \mathrm{C}$ based on hourly measurements. 
Table 1. Composition and analysis of textured (TX), pelleted (P), and meal (MT) starter feeds from trials 1 and 2

\begin{tabular}{|c|c|c|c|c|}
\hline \multirow[b]{2}{*}{ Item } & \multicolumn{2}{|c|}{ Trial 1} & \multicolumn{2}{|c|}{ Trial 2} \\
\hline & $\mathrm{TX}$ & $\mathrm{P}$ & TX & MT \\
\hline \multicolumn{5}{|l|}{ Ingredient, $\%$ as-fed } \\
\hline Corn, rolled coarse & 40.00 & - & 40.00 & \\
\hline Corn, rolled fine & & & & 40.00 \\
\hline Oats, whole & 20.00 & - & 20.00 & \\
\hline Oat, rolled fine & & & & 20.00 \\
\hline Molasses, cane & 5.00 & $5.00^{1}$ & 5.00 & 5.00 \\
\hline Corn, rolled fine & - & $46.00^{1}$ & - & \\
\hline Soybean meal, $48 \% \mathrm{CP}$ & $22.86^{1}$ & $20.16^{1}$ & $22.86^{1}$ & 22.86 \\
\hline Wheat middlings & $6.80^{1}$ & $20.00^{1}$ & $6.80^{1}$ & 6.80 \\
\hline Alfalfa meal & $1.31^{1}$ & $5.00^{1}$ & $1.31^{1}$ & 1.31 \\
\hline Minerals $^{2}$ & $2.88^{1}$ & $2.59^{1}$ & $2.88^{1}$ & 2.88 \\
\hline Vitamins and trace minerals ${ }^{3}$ & $0.75^{1}$ & $0.75^{1}$ & $0.75^{1}$ & 0.75 \\
\hline Fat & $0.35^{1}$ & - & $0.35^{1}$ & 0.35 \\
\hline Decoquinate $^{4}$ & $0.05^{1}$ & $0.50^{1}$ & $0.05^{1}$ & 0.05 \\
\hline \multicolumn{5}{|l|}{ Assayed nutrient } \\
\hline $\mathrm{DM}, \%$ & 88.9 & 88.6 & 88.3 & 88.8 \\
\hline $\mathrm{CP}, \%$ of DM & 20.5 & 20.4 & 20.0 & 21.0 \\
\hline $\mathrm{ADF}, \%$ of $\mathrm{DM}$ & 7.0 & 7.1 & 7.7 & 7.2 \\
\hline $\mathrm{NDF}, \%$ of DM & 15.2 & 16.1 & 15.7 & 15.2 \\
\hline $\mathrm{Ca}, \%$ of $\mathrm{DM}$ & 0.9 & 0.9 & 0.9 & 0.9 \\
\hline $\mathrm{P}, \%$ of $\mathrm{DM}$ & 0.6 & 0.6 & 0.6 & 0.6 \\
\hline $\mathrm{K}, \%$ of $\mathrm{DM}$ & 1.0 & 1.1 & 1.0 & 0.9 \\
\hline $\mathrm{Mg}, \%$ of $\mathrm{DM}$ & 0.2 & 0.2 & 0.2 & 0.2 \\
\hline Geometric mean particle size, $\mu \mathrm{m}$ & 2,103 & 735 & 2,029 & 813 \\
\hline Particles $>1,180 \mu \mathrm{m}, \%$ & 82 & 3 & 81 & 4 \\
\hline \multicolumn{5}{|l|}{${ }^{1}$ Combined in a pellet. } \\
\hline \multicolumn{5}{|c|}{${ }^{2}$ Calcium carbonate, dicalcium phosphate, and salt. } \\
\hline \multicolumn{5}{|c|}{$\begin{array}{l}{ }^{3} \text { Contained per kilogram of starter: } 1.60 \mathrm{~g} \mathrm{Cu}, 0.13 \mathrm{~g} \mathrm{Co}, 9.40 \mathrm{~g} \mathrm{Fe}, 0.14 \mathrm{~g} \mathrm{I}, 5.4 \mathrm{~g} \mathrm{Mn}, 0.04 \mathrm{~g} \mathrm{Se}, 6.70 \mathrm{~g} \mathrm{Zn} \\
1,800 \mathrm{kIU} \text { vitamin A, } 600 \mathrm{kIU} \text { vitamin } \mathrm{D}, 16 \mathrm{kIU} \text { vitamin E, } 0.01 \mathrm{~g} \text { biotin, } 2.93 \mathrm{~g} \text { cobalamin, } 0.04 \mathrm{~g} \text { folic acid } \\
1.77 \mathrm{~g} \text { niacin, } 1.32 \mathrm{~g} \text { pantothenic acid, } 0.24 \text { pyridoxine, } 0.30 \mathrm{riboflavin}, 0.29 \mathrm{~g} \text { thiamin; Akey, Lewisburg, } \mathrm{OH} \text {. } \\
{ }^{4} \text { Concentration: } 60 \mathrm{~g} / \mathrm{kg} \text { product used in manufacture of } \mathrm{TX}, 5 \mathrm{~g} / \mathrm{kg} \text { product used in manufacture of P } \\
\text { Alpharma Inc., Fort Lee, NJ. }\end{array}$} \\
\hline
\end{tabular}

Trial 4 compared feeding weaned Holstein steer calves TS or TR starters (Table 2) from the same corn source. Particle size distribution of chopped hay was measured by a dry sieving method (Shaver et al., 1988) using a vibratory sieve shaker (Fritsch) and geometric mean particle size was determined (ASAE, 1983). Starters had a geometric mean particles sizes of 2,257 (TS) and $2,289 \mu \mathrm{m}$ (TR) and over $83 \%$ of the particles were $>1,180 \mu \mathrm{m}$. The starters were formulated to have identical ingredient and nutrient concentrations. Chopped grass hay (mean geometric particle size of 2,232 $\mu \mathrm{m}$ ) was blended with the starters (5\% wt/wt) before feeding. Starters and water were fed ad libitum. Calves for this trial were previously used in trial 3. Calves were blocked by previous treatment and randomly assigned to treatments. Calves ( $48 ; 24$ calves per treatment) were maintained in group pens of 6 calves per pen. Trial 4 lasted $28 \mathrm{~d}$ and was conducted from June through July. The average temperature was $24^{\circ} \mathrm{C}$ and ranged from 10 to $34^{\circ} \mathrm{C}$ based on hourly measurements.

Trial 5 compared feeding weaned Holstein steer calves starters TW or TR (Table 2) from the same corn source. Starters had geometric mean particle sizes of $2,895(\mathrm{TW})$ and $2,042 \mu \mathrm{m}$ (TR) and over $81 \%$ of the particles were $>1,180 \mu \mathrm{m}$. Starters were formulated to have identical ingredient and nutrient concentrations. Chopped grass hay (mean geometric particle size of $2,216 \mu \mathrm{m})$ was blended ( $5 \% \mathrm{wt} / \mathrm{wt}$ ) with starters before feeding. Starters and water were fed ad libitum. Calves used in this trial were previously used in an unrelated MR trial and were $8 \mathrm{wk}$ old when this trial began. Calves were blocked by previous MR treatment and randomly assigned to pens. Calves (48; 24 calves per treatment) were maintained in group pens of 6 calves per pen. Trial 5 lasted $28 \mathrm{~d}$ and was conducted March through April. The average ambient temperature in the calf housing area during the trial was $11^{\circ} \mathrm{C}$ and ranged from 0 to $28^{\circ} \mathrm{C}$ based on hourly measurements.

Individual pens used in trials 1,2 , and 3 were 1.2 by $2.4 \mathrm{~m}$ within a curtain sidewall barn with no added heat. The group pens used in trials 4 and 5 consisted of $5.5 \mathrm{~m}^{2}$ of outside pen space and $0.9 \mathrm{~m}^{2}$ of inside pen space per calf. The individual pens and inside pen space in the group pens were bedded with straw. 
Table 2. Composition and analysis of starter feeds containing whole (TW), steam flaked (TS), or dry rolled (TR) corn from trials 3 , 4, and 5

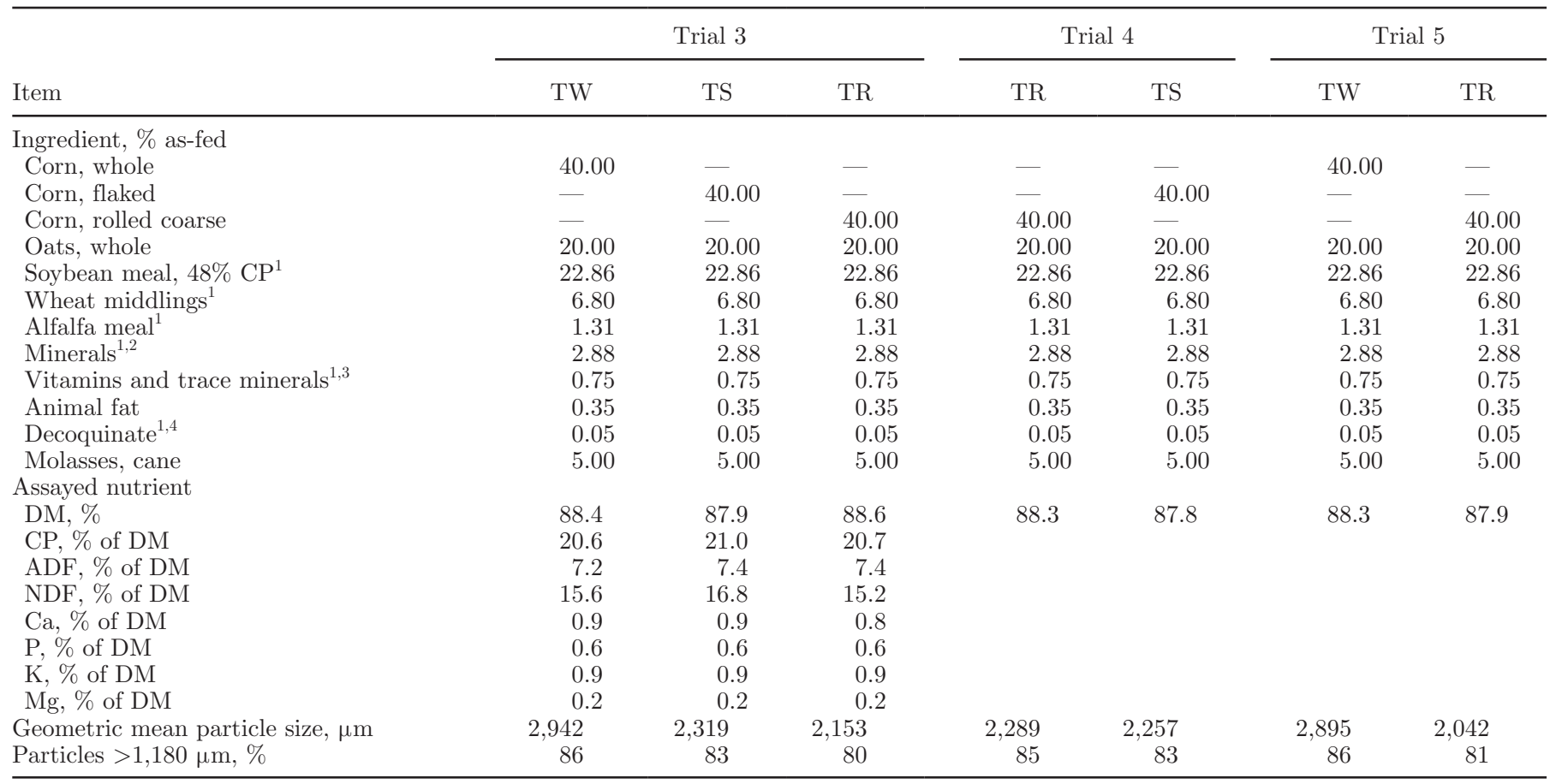

${ }^{1}$ Combined in a pellet.

${ }^{2}$ Calcium carbonate, dicalcium phosphate, and salt.

${ }^{3}$ Contained per kilogram of starter: $1.60 \mathrm{~g} \mathrm{Cu}, 0.13 \mathrm{~g} \mathrm{Co}, 9.40 \mathrm{~g} \mathrm{Fe}, 0.14 \mathrm{~g} \mathrm{I}, 5.4 \mathrm{~g} \mathrm{Mn}, 0.04 \mathrm{~g}$ Se, $6.70 \mathrm{~g}$ Zn, $1,800 \mathrm{kIU}$ vitamin A, $600 \mathrm{kIU}$ vitamin D, $16 \mathrm{kIU}$ vitamin E, $0.01 \mathrm{~g}$ biotin, $2.93 \mathrm{~g}$ cobalamin, $0.04 \mathrm{~g}$ folic acid, $1.77 \mathrm{~g}$ niacin, $1.32 \mathrm{~g}$ pantothenic acid, 0.24 pyridoxine, 0.30 riboflavin, $0.29 \mathrm{~g}$ thiamin; Akey, Lewisburg, $\mathrm{OH}$.

${ }^{4}$ Concentration: $60 \mathrm{~g} / \mathrm{kg}$ product; Alpharma Inc., Fort Lee, NJ.

Calves in trials 1,2 , and 3 were weighed initially at approximately $1200 \mathrm{~h}$ on $\mathrm{d} 0$ of the trial and every $7 \mathrm{~d}$ until the end of the trial (d 56). Calves in trials 4 and 5 were weighed at approximately $1200 \mathrm{~h}$ on $\mathrm{d} 0$ of the trial and at the end of the trial (d 28). Dry feed offered and feed refusals were weighed daily in all trials. Fecal scores were assigned daily based on a 1 to 5 system (1 being normal, thick in consistency; 2 being normal, but less thick; 3 being abnormally thin but not watery; 4 being watery; 5 being watery with abnormal coloring) while calves were in individual pens. Fecal scores were not assigned for calves in the group pens. However, these calves were monitored daily and did not appear to have fecal scores exceeding 2 . Hip widths were measured with a caliper and BCS of calves in individual pens were measured during the initial (d 0) measurement period and every 2 wk thereafter. A 1 to 5 system using 0.25 -unit increments with 1 being emaciated and 5 being obese was used for BCS (Wildman et al., 1982). Scores were based on changes around the vertical and transverse processes of the spine as palpated by one experienced technician and ranged from 1.5 to 3.5. Hip width and BCS of calves in group pens were measured at the beginning and end of the trial.

Calves received an intranasal tissue sensitive respiratory disease vaccine (TSV-2, Pfizer, Exton, PA) and subcutaneous injections of vitamins $\mathrm{A}, \mathrm{D}$, and $\mathrm{E}$ (Vital E - A + D, Schering-Plough Animal Health, Union, NJ) and Se (MU-SE, Schering-Plough Animal Health) upon arrival. Calves received an intramuscular respiratory disease vaccine (Bovashield Gold 5, Pfizer) at d 7 and again at $\mathrm{d} 28$. At d 14 they received an intramuscular vaccine for types $\mathrm{C}$ and D clostridium (Ultra Choice 7, Pfizer). A pasteurella vaccine (Presponse HM, Fort Dodge, Fort Dodge, IA) was administered intramuscularly on d 28 and 42. Calves were castrated and dehorned at $36 \mathrm{~d}$ of age. Animals that required medication for intestinal (subcutaneous ceftiofur sodium, Naxcel, Pharmacia \& Upjohn, Kalamazoo, MI) or navel (subcutaneous penicillin G procaine, Agri-Cillin, AgriLabs, St. Joseph, MO) infections were treated per veterinary recommendation and treatments were recorded daily. One calf on each treatment in trial 1 and one calf on treatment $\mathrm{R}$ in trial 3 received treatments 
Table 3. Distribution (\% retained on a screen with nominal opening) of particles in starters ${ }^{1}$ fed in trials 1, 2, 3, 4, and 5

\begin{tabular}{|c|c|c|c|c|c|c|c|c|c|c|c|}
\hline $\begin{array}{l}\text { Opening, } \\
\mu \mathrm{m}\end{array}$ & \multicolumn{2}{|c|}{ Trial 1} & \multicolumn{2}{|c|}{ Trial 2} & \multicolumn{3}{|c|}{ Trial 3} & \multicolumn{2}{|c|}{ Trial 4} & \multicolumn{2}{|c|}{ Trial 5} \\
\hline 3,350 & 35.3 & 0.0 & 32.3 & 0.0 & 80.1 & 46.9 & 42.3 & 37.0 & 42.0 & 78.9 & 31.0 \\
\hline 1,700 & 16.1 & 0.0 & 16.7 & 0.0 & 0.1 & 13.4 & 11.5 & 13.5 & 12.6 & 0.2 & 16.3 \\
\hline 1,180 & 12.1 & 3.2 & 12.5 & 4.4 & 6.8 & 7.5 & 9.2 & 9.7 & 8.3 & 7.0 & 10.1 \\
\hline 850 & 6.1 & 39.5 & 6.7 & 64.5 & 4.8 & 5.8 & 7.0 & 5.9 & 6.2 & 4.8 & 6.1 \\
\hline 212 & 1.9 & 4.4 & 1.8 & 4.0 & 0.4 & 1.2 & 2.0 & 1.0 & 1.5 & 0.3 & 1.7 \\
\hline 150 & 0.5 & 1.1 & 0.7 & 1.2 & 0.3 & 0.4 & 0.8 & 0.9 & 0.7 & 0.4 & 1.0 \\
\hline 106 & $<0.05$ & $<0.05$ & $<0.05$ & $<0.05$ & $<0.05$ & $<0.05$ & $<0.05$ & $<0.05$ & $<0.05$ & $<0.05$ & $<0.05$ \\
\hline Pan & $<0.05$ & $<0.05$ & $<0.05$ & $<0.05$ & $<0.05$ & $<0.05$ & $<0.05$ & $<0.05$ & $<0.05$ & $<0.05$ & $<0.05$ \\
\hline
\end{tabular}

${ }^{1} \mathrm{TX}=$ textured, $\mathrm{P}=$ pelleted, MT $=$ half textured $/$ half meal starter (by weight), TW $=$ whole corn, $\mathrm{TS}=$ steam flaked corn, $\mathrm{TR}=\mathrm{dry}$ rolled corn.

for navel infections. All other medical treatments were because of intestinal upsets (scouring) and occurred in trials 1, 2, and 3. Intestinal infections were diagnosed based on rectal temperatures $>39.5^{\circ} \mathrm{C}$, lack of vitality, and fecal scores $>2$.

Approximately $110 \%$ of the estimated feeds needed for each trial was manufactured as a single batch. Samples of manufactured feeds were collected from every second bag $(22.7 \mathrm{~kg})$ of feed at the time of manufacture. Approximately $120 \%$ of the estimated hay needed for each trial was purchased as a single lot and samples were taken from each bale (approximately 20$\mathrm{kg}$ bales). Samples were composited and the composites were analyzed (AOAC, 1996) before the trials for DM (oven method; method 930.15), CP (Kjeldahl method; method 988.05), and Ca, P, K, and Mg (dry ashing, acid digestion, analysis by ICP; method 985.01). Additionally, feeds were analyzed for NDF with ash by the procedure of Van Soest et al. (1991) without sodium sulfite or $\alpha$-amylase, and ADF with ash (Robertson and Van Soest, 1981). The hay fed in the group pens of trials 4 and 5 was a mixed, mostly grass hay (timothy, Phleum pratense L.) and contained 88.5\% DM, $15.7 \%$ $\mathrm{CP}, 36.4 \% \mathrm{ADF}$, and $56.2 \% \mathrm{NDF}$ (DM basis) in trial 4, and $87.9 \% \mathrm{DM}, 15.2 \% \mathrm{CP}, 38.1 \% \mathrm{ADF}$, and $57.9 \%$ NDF (DM basis) in trial 5 .

Data from each trial were analyzed separately using the MIXED procedure in SAS (Version 8, SAS Institute Inc., Cary, NC). Trials 1, 2, and 3 were analyzed as completely randomized designs. Calf within treatment was a random effect used to test the fixed effect of treatment. Day was a repeated measure using an autoregressive type 1 covariance structure within preweaning and postweaning periods. Data reported are least squares means for the experimental unit of calf. Trials 4 and 5 were analyzed as randomized complete block designs.
Block and pen were random effects and treatment was a fixed effect. Data reported are least squares means for the experimental unit of pen.

\section{RESULTS}

Particle size distributions of the different starters fed during this study are presented in Table 3. All starters except starter $\mathrm{P}$ in trial 1 and starter MT in trial $2 \mathrm{had}$ a mean particle size $>2,000 \mu \mathrm{m}$ and more than $80 \%$ of the particles retained on a screen with $1,180 \mu \mathrm{m}$ nominal opening.

Initial measurements of BW, hip width, BCS, and serum protein did not differ in any trial. Treatment means in trial 1 did not differ. Average performance measurements for trial 1 were $0.585 \pm 0.041 \mathrm{~kg} / \mathrm{d}$ ADG, $0.815 \pm 0.068 \mathrm{~kg} / \mathrm{d}$ starter intake, $0.498 \pm 0.039$ feed efficiency, $4.0 \pm 0.9$ abnormal fecal score d, $4.0 \pm 0.3$ $\mathrm{cm}$ hip width change, and $0.8 \pm 0.1$ BCS change.

In trial 2, postweaning (d 28 to 56) starter intake was $11 \%$ less (Table 4) and overall (d 0 to 56) starter intake was $11 \%$ less in calves fed MT versus TX. Calves fed MT grew $7 \%$ slower from d 28 to 56 and $6 \%$ slower from d 0 to 56 than calves fed TX. Calves fed MT had less hip width change from d 28 to 56 and less hip width change from d 0 to 56 than calves fed TX. Other measurements did not differ.

In trial 3, there were no differences in any measurement during the trial. Average performance measurements for the 56 -d trial were $0.590 \pm 0.028 \mathrm{~kg} / \mathrm{d}$ ADG, $0.971 \pm 0.059 \mathrm{~kg} / \mathrm{d}$ starter intake, $0.427 \pm 0.027$ feed efficiency, $2.1 \pm 0.4$ abnormal fecal score d, $3.6 \pm 0.2$ $\mathrm{cm}$ hip width change, and $0.4 \pm 0.1$ BCS change.

There were no differences in any measurement during trial 4. Average performance measurements for the 28 -d trial were $0.977 \pm 0.034 \mathrm{~kg} / \mathrm{d}$ ADG, $3.012 \pm 0.074$ 
Table 4. Effect of feeding a textured starter or half of a textured starter and half of a meal starter on calf performance (28 d) in trial 2

\begin{tabular}{|c|c|c|c|c|}
\hline Item & $\begin{array}{l}\text { TX Textured } \\
\text { starter }\end{array}$ & $\begin{array}{l}\text { MT } 50 \% \text { Textured, } \\
50 \% \text { meal starter }\end{array}$ & SEM & $P$-value \\
\hline Calves, $\mathrm{n}$ & 24 & 24 & - & \\
\hline Initial serum protein, $\mathrm{mg} / \mathrm{dL}$ & 4.9 & 5.1 & 0.43 & 0.65 \\
\hline Ending BW, kg & 80.1 & 77.3 & 1.37 & 0.06 \\
\hline \multicolumn{5}{|l|}{$\mathrm{ADG}, \mathrm{kg} / \mathrm{d}$} \\
\hline d 0 to 28 & 0.521 & 0.499 & 0.0228 & 0.23 \\
\hline \multicolumn{5}{|l|}{ Starter intake, $\mathrm{kg} / \mathrm{d}$} \\
\hline d 0 to 28 & 0.283 & 0.257 & 0.0330 & 0.33 \\
\hline d 28 to 56 & 2.184 & 1.936 & 0.1106 & 0.03 \\
\hline d 0 to 56 & 1.234 & 1.097 & 0.05489 & 0.04 \\
\hline \multicolumn{5}{|l|}{ Milk replacer intake, $\mathrm{kg} / \mathrm{d}$} \\
\hline d 0 to 28 & 0.591 & 0.591 & - & - \\
\hline d 28 to 56 & - & - & - & - \\
\hline \multicolumn{5}{|l|}{ Abnormal fecal score days ${ }^{1}$} \\
\hline d 0 to 28 & 0.6 & 0.5 & 0.2 & 0.76 \\
\hline d 28 to 56 & 0.1 & 0.2 & 0.1 & 0.89 \\
\hline \multirow{2}{*}{\multicolumn{5}{|c|}{$\mathrm{BCS}^{2}$}} \\
\hline & & & & \\
\hline Initial & 2.2 & 2.3 & 0.074 & 0.45 \\
\hline d 0 to 28 change & 0.1 & 0.1 & 0.07 & 0.78 \\
\hline d 28 to 56 change & 0.3 & 0.3 & 0.08 & 0.84 \\
\hline d 0 to 56 change & 0.4 & 0.4 & 0.08 & 0.78 \\
\hline \multicolumn{5}{|l|}{ Hip width, cm } \\
\hline Initial & 17.3 & 17.5 & 0.59 & 0.87 \\
\hline d 0 to 28 change & 1.8 & 1.7 & 0.14 & 0.95 \\
\hline d 28 to 56 change & 2.7 & 2.4 & 0.11 & 0.04 \\
\hline d 0 to 56 change & 4.5 & 4.1 & 0.15 & 0.05 \\
\hline
\end{tabular}

${ }^{1}$ Fecal score system: $1=$ normal, thick in consistency; $2=$ normal, but less thick; $3=$ abnormally thin but not watery; $4=$ watery; $5=$ watery with abnormal coloring. Abnormal fecal score days were days with fecal scores $>2$.

${ }^{2} \mathrm{BCS}$ system: 1 to 5 with $1=$ emaciated and $5=$ obese.

$\mathrm{kg} / \mathrm{d}$ starter intake, $0.323 \pm 0.012$ feed efficiency, $2.8 \pm$ $0.2 \mathrm{~cm}$ hip width change, and $0.2 \pm 0.05$ BCS change.

There were no differences in any measurement during trial 5. Average performance measurements for the 28 -d trial were $1.206 \pm 0.043 \mathrm{~kg} / \mathrm{d}$ ADG, $3.389 \pm 0.152$ $\mathrm{kg} / \mathrm{d}$ starter intake, $0.355 \pm 0.043$ feed efficiency, $3.9 \pm$ $0.3 \mathrm{~cm}$ hip width change, and $0.2 \pm 0.04$ BCS change.

\section{DISCUSSION}

Cereal grains are often processed before feeding to increase digestion of the starch and other nutrients. Steam flaking and roasting gelatinizes the starch of corn, thus increasing the ability of microbes and enzymes to hydrolyze the starch granule. Fine grinding increases the surface area of the grain, thus increasing the potential attachment sites for microbes or enzymes. However, reports of improvement in calf growth when feeding processed grains are limited. Lassiter et al. (1955), Gardner (1967), and Kertz et al. (1979) have all reported that calves consume less of starters that are fine meals versus starters with large particles. However, these papers did not report many details of how calves were housed and managed. There are 4 more recent publications that compare form and particle size of starters for calves (Franklin et al., 2003; Coverdale et al., 2004; Bach et al., 2007; Porter et al., 2007), yet each of these can be criticized for varying reasons that confound interpretation of their results.

Franklin et al. (2003) reported less preweaning starter intake and ADG in calves fed a pelleted starter; however, starters were not equal in CP, additives, molasses, protein sources, and several other ingredients and nutrients. Coverdale et al. (2004) restricted starter intake and reported improved ADG when calves were fed a textured starter compared with a fine ground starter; however, this effect was not present when calves were allowed ad libitum access to the different starters. Bach et al. (2007) fed identical diets either as a pellet or a coarse mash to calves and reported better efficiency 
of gain but lower starter intake with a pelleted diet postweaning. However, Kertz (2007) criticized the study for not discussing the impact of bedding consumption by the calves fed the pelleted diet. Porter et al. (2007) reported greater ADG, starter intake, and earlier initiation of rumination in neonatal calves fed a coarse meal diet versus a fine ground diet that had been pelleted. Hill et al. (2008a) concluded that when starter feeds had mean particle size of approximately $2,000 \mu \mathrm{m}$, increasing fiber content depressed ADG probably due to gut fill interfering with energy intake.

In trial 1, both diets presented to calves had coarse particles; however, in trial 2 , diet TX was coarse but diet MT intentionally contained fine particles. Diet MT was not consumed as well and in turn reduced ADG compared with TX although efficiency was not changed. In trial 3, only the particle size and processing of the corn varied. These data indicate that processing of corn was not related to ADG or feed efficiency of calves but that starter intake was reduced in calves presented with finely processed feeds that were not pelleted, resulting in reduced ADG. We observed no differences in starter intake when a completely pelleted starter was fed compared with a textured starter. Mean particle sizes of the textured starters fed in trial 1 and 2 were similar as were the mean particle sizes of the pelleted and meal starters in these 2 trials. However, the wet sieving process used for measurement of particle size would destroy supplement pellets and therefore may not accurately represent the particle size presented or consumed by the calves. Our data appear to agree with recommendations of Porter et al. (2007) and Hill et al. (2008a) that when calves were presented starters that had greater than $75 \%$ of particles of $1,190 \mu \mathrm{m}$ or greater, calf performance was not impaired. Unfortunately, mean particle size of the starters used by Franklin et al. (2003), Bach et al. (2007), and Coverdale et al. (2004) were not reported.

Kertz (2007) emphasized that allowing calves to consume bedding material was likely a key management practice to reduce acidosis and allow for ADG in instances where starters containing finely processed grains are fed. Results of the current trials must be viewed with the understanding that all calves were maintained on straw bedding and the calves over $8 \mathrm{wk}$ of age were fed chopped grass hay (5\% wt/wt) with their starter. In trials 1, 3, 4, and 5, form, particle size, or processing (whole, dry rolled, or steam flaked) of the corn in the coarse textured starters and one completely pelleted starter (all with similar ingredient and nutrient compositions) did not change ADG, starter intake, efficiency, or any other measurement made in calves from less than $1 \mathrm{wk}$ to $12 \mathrm{wk}$ of age. In trial 2, when identical diets were fed but one diet intentionally contained fines, calf intake was reduced by $11 \%$ and ADG was reduced by $6 \%$ versus calves fed $100 \%$ coarse textured starter with few small particles. This suggests a poor acceptability by calves of a starter containing many fines (unpelleted), which results in reduced starter intake and ADG.

\section{CONCLUSIONS}

When calves were bedded with straw or fed chopped grass hay, processing cereal grains during manufacture of calf starters had little impact on calf growth unless a large portion of the starter had a small particle size. Processing starters to reduce the amount of fine particles present increased feed intake and resulted in improvements in calf performance.

\section{REFERENCES}

Abdelgadir, I. E. O., and J. L. Morrill. 1995. Effect of processing sorghum grain on dairy calf performance. J. Dairy Sci. 78:20402046.

Abdelgadir, I. E. O., J. L. Morrill, and J. J. Higgins. 1996a. Ruminal availabilities of protein and starch: Effects on growth and ruminal and plasma metabolites of dairy calves. J. Dairy Sci. 79:283290 .

Abdelgadir, I. E. O., J. L. Morrill, and J. J. Higgins. 1996b. Effect of roasted soybeans and corn on performance and ruminal and blood metabolites of dairy calves. J. Dairy Sci. 79:465-474.

AOAC. 1996. Official Methods of Analysis. 16th ed. Association of Official Analytical Chemists, Arlington, VA.

ASAE. 1983. Method of determining and expressing fineness of feed materials by sieving. Page 325 in ASAE Standard S319, Agriculture Engineers Yearbook of Standards. Am. Soc. Agric. Eng., St. Joseph, MI.

Bach, A., A. Gimenez, J. L. Juaristi, and J. Ahedo. 2007. Effects of physical form of a starter for dairy replacement calves on feed intake and performance. J. Dairy Sci. 90:3028-3033.

Coverdale, J. A., H. D. Tyler, J. D. Quigley III, and J. A. Brumm. 2004. Effect of various levels of forage and form of diet on rumen development and growth in calves. J. Dairy Sci. 87:2554-2562.

FASS. 1999. Guide for the Care and Use of Agricultural Animals in Agricultural Research and Teaching. 1st rev. ed. Federation of Animal Science Societies, Savoy, IL.

Franklin, S. T., D. M. Amaral-Phillips, J. A. Jackson, and A. A. Cambell. 2003. Health and performance of Holstein calves that suckled or were hand-fed colostrums and were fed one of three physical forms of starter. J. Dairy Sci. 86:2145-2153.

Gardner, R. W. 1967. Acceptability and nutritional response comparisons between calf starters. J. Dairy Sci. 50:729-734.

Greenwood, R. H., J. L. Morril, E. C. Titgemeyer, and G. A. Kennedy. 1997. A new method of measuring diet abrasion and its effect on the development of the forestomach. J. Dairy Sci. 80:2534-2541.

Healy, B. J., J. D. Hancock, G. A. Kennedy, P. J. Bramel-Cox, K. C. Behnke, and R. H. Hines. 1994. Optimum particle size of corn and hard and soft sorghum for nursery pigs. J. Anim. Sci. 72:22272236 .

Hill, T. M., H. G. Bateman, J. M. Aldrich, and R. L. Schlotterbeck. 2008a. Effects of the amount of chopped hay or cottonseed hulls in a textured calf starter on young calf performance. J. Dairy Sci. 91:2684-2693.

Hill, T. M., H. G. Bateman, J. M. Aldrich, and R. L. Schlotterbeck. 2008b. Effect of feeding different carbohydrate sources and amounts to young calves. J. Dairy Sci. 91:3128-3137.

Kertz, A. F. 2007. Letter to the editor: Pelleted calf starter with straw access can confound results: A comment on Bach et al. (2007). J. Dairy Sci. 90:4924. 
Kertz, A. F., L. R. Prewitt, and J. P. Everett Jr. 1979. An early weaning calf program: Summarization and review. J. Dairy Sci. 62:1835-1843.

Lassiter, C. A., T. W. Denton, L. D. Brown, and J. W. Rust. 1955 The nutritional merits of pelleting calf starters. J. Dairy Sci. 38:1242-1245.

Lesmeister, K. E., and A. J. Heinrichs. 2004. Effects of corn processing on growth characteristics, rumen development, and rumen parameters in neonatal dairy calves. J. Dairy Sci. 87:3439-3450.

Lesmeister, K. E., and A. J. Heinrichs. 2005. Effects of adding extra molasses to a texturized calf starter on rumen development, growth characteristics, and blood parameters in neonatal dairy calves. J. Dairy Sci. 88:411-418.

Porter, J. C., R. G. Warner, and A. F. Kertz. 2007. Effect of fiber level and physical form of starter on growth and development of dairy calves fed no forage. Prof. Anim. Sci. 23:395-400.

Remond, D., J. I. Cabrera-Estrada, M. Champion, B. Chauveau, R. Coudure, and C. Poncet. 2004. Effect of corn particle size on site and extent of starch digestion in lactating dairy cows. J. Dairy Sci. 87:1389-1399.

Robertson, J. B., and P. J. Van Soest. 1981. The Detergent System of Analysis and its Application to Human Foods. Cornell University, Ithaca, NY.

Shaver, R. D., A. J. Nytes, L. D. Satter, and N. A. Jorgensen. 1988. Influence of feed intake, forage physical form, and forage fiber content on particle size of masticated forage, ruminal digesta, and feces of dairy cattle. J. Dairy Sci. 71:1566-1572.

Van Soest, P. J., J. B. Robertson, and B. A. Lewis. 1991. Methods for dietary fiber, neutral detergent fiber, non-starch polysaccharides in relation to animal nutrition. J. Dairy Sci. 74:3583-3597.

Wildman, E. E., G. M. Jones, P. E. Wagner, R. L. Bowman, H. F. Troutt Jr., and T. N. Lesch. 1982. A dairy cow body condition scoring system and its relationship to selected production characteristics. J. Dairy Sci. 65:495-501. 